ROCZNIKI KULTUROZNAWCZE

Tom X, numer $4 \quad-\quad 2019$

DOI: http://dx.doi.org/10.18290/rkult.2019.10.4-6

PAWEŁ GONDEK

\title{
SPECYFIKA SPRAWNOŚCIOWEGO \\ ROZUMIENIA INTELEKTUALIZACJI W KULTUROTWÓRCZYM DZIAŁANIU CZŁOWIEKA
}

Rozpatrywanie kultury od strony uczestniczącego w niej człowieka stanowi zjawisko złożone. Ujawnia się bowiem wieloaspektowy wymiar tego uczestniczenia oraz różne sposoby jego realizacji przez człowieka. Próby ujęcia problematyki kultury w jedną i spójną całość z konieczności muszą opierać się na definicyjnym określeniu, w którym zawarty będzie jej istotowy sens. Propozycją takiego sformułowania jest, powstałe na bazie filozofii arystotelesowsko-tomistycznej, określenie kultury jako ,intelektualizacji natury” (Mieczysław A. Krąpiec). Jest to do pewnego stopnia skrót myślowy, który $\mathrm{w}$ zamierzeniu ma wyrazić sens tego, czym kultura jest w swej istocie. Doprecyzowania wymagają jednak zarówno same pojęcia „intelektualizacja” i „natura”, jak i znaczeniowa specyfika połączenia tych dwóch terminów. Problematyka dotycząca natury w kontekście intelektualizacji oraz postrzeganego z tej perspektywy związku między nimi była już przedmiotem badań ${ }^{1}$. Natomiast rozumienie intelektualizacji nie wydaje się do końca sprecyzowane, szczególnie gdy weźmiemy pod uwagę człowieka jako twórcę kultury, a zwłaszcza zachodzące $\mathrm{w}$ nim procesy intelektualne, w których owa intelektualizacja jakoś się dokonuje.

W rozpatrywaniu tego zagadnienia nie będzie wystarczającym zabiegiem ukazanie specyfiki ludzkiego poznania, ponieważ intelektualizacja nie wyczerpuje się w samych aktach poznawczych. Równie ważne jest to, co dzieje

Dr hab. PAweŁ GondeK - Katolicki Uniwersytet Lubelski Jana Pawła II, Wydział Filozofii, Katedra Filozofii Kultury i Podstaw Retoryki; adres do korespondencji — e-mail: pawel. gondek@kul.pl. ORCID: https://orcid.org/0000-0002-8644-3886.

${ }^{1}$ Por. Tomasz DumA, „Natura miarą sensu kultury”, Zeszyty Naukowe KUL 58, nr 1 (2015): $35-49$. 
się później, czyli jak konstytuują się rezultaty procesów intelektualnych oraz jaka jest ich relacja do innych aktów osobowych. Filozofia kultury jest rozumiana w tej tradycji jako dyscyplina szczegółowa antropologii filozoficznej i obejmuje swym zakresem badawczym sposoby realizowania się osobowego bytowania człowieka $\mathrm{w}$ świecie ${ }^{2}$. Dlatego wyróżniane $\mathrm{w}$ tym kontekście działy kultury są jednocześnie obszarami osobowego doskonalenia się człowieka. $Z$ tej racji intelektualizacja musi mieć także podmiotowe uwarunkowania czynnościowe, które stanowią o możliwości osobowego doskonalenia się człowieka. W wyjaśnieniu tego zagadnienia odnosimy się do sprawności intelektualnych, których udział w procesach ludzkiego poznania i rozumowania podkreślany jest już od starożytności. Sprawności intelektualne, określane też jako cnoty dianoetyczne, są specjalnym uzdolnieniem człowieka w porządku intelektualnym. W tym kontekście wydają się one ogrywać kluczową rolę zarówno w działaniach kulturotwórczych, jak i w osobowym doskonaleniu się człowieka.

W tekście zostanie przedstawiona propozycja rozumienia sprawności intelektualnych jako istotnej podstawy realizowania się intelektualizacji. Odniesiemy się w tych badaniach do filozofów z kręgu lubelskiej szkoły filozoficznej (Mieczysław A. Krąpiec, Jerzy Kalinowski, Stanisław Kamiński), ukazując ich rozwiązania $w$ tym zakresie. Powstała $w$ tym nurcie filozoficzna koncepcja podstaw rozumienia kultury wydaje się już w pełni opracowana ${ }^{3}$. W tym jednak całościowym zarysie niejednokrotnie występuje potrzeba doprecyzowania jej szczegółowych zagadnień, co owocuje częstym powracaniem w różnych publikacjach do tego zagadnienia. Tak też jest z określeniem ,intelektualizacja”, które w filozoficznych badaniach nad kulturą jest wielokrotnie przywoływane, a jednak pozostaje niewyjaśnione. Propozycja jego doprecyzowania, przedstawiona w poniższym tekście, ma na celu wskazanie metodologicznych podstaw rozumienia intelektualizacji w perspektywie realizowania się sprawności intelektualnych w człowieku. Ze względu na kontekst użycia tego określenia należy w pierwszym rzędzie

\footnotetext{
${ }^{2}$ Por. Paweł GondeK, Projekt autonomicznej filozofii realistycznej. Mieczysława A. Krapca i Stanisława Kamińskiego teoria bytu (Lublin: Wydawnictwo KUL i Polskie Towarzystwo Tomasza z Akwinu, 2015), 247. Metodologicznego uzasadnienia filozofii kultury jako dyscypliny wyróżnionej w ramach metafizyki realistycznej dokonuje Wojciech Daszkiewicz w monografii Byt. Człowiek. Kultura. Studium z filozofii kultury (Lublin: Polskie Towarzystwo Tomasza z Akwinu, 2019).

${ }^{3}$ Wskazuje się tu głównie na prace Mieczysława A. Krąpca, a w sposób szczególny na rozprawę U podstaw rozumienia kultury (Lublin: Redakcja Wydawnictw KUL, 1991). Drugie, poszerzone wydanie tej pracy ukazało się jako: Mieczysław A. KRĄPIEC, Człowiek i kultura (Lublin: Polskie Towarzystwo Tomasza z Akwinu, 2008).
} 
skoncentrować się na tradycji arystotelesowsko-tomistycznej, która historycznie i koncepcyjne odpowiada podejściu realistycznemu.

\section{INTELEKTUALIZACJA \\ PRZEZ SPRAWNOŚCI INTELEKTUALNE}

Rozumienie kultury jako intelektualizacji natury czerpie swoje uzasadnienie z tradycji klasycznej, sięgającej starożytności. Wskazując na genezę takiego podejścia, Mieczysław A. Krąpiec przywołuje zawarte w Rozmowach tuskulańskich Cycerona wyjaśnienie kultury jako „uprawy duszy” (animi cultura $)^{4}$. Cyceroniańska „uprawa” dotyczy człowieka jako bytu spotencjalizowanego, który zawiera $\mathrm{w}$ sobie zdolność do doskonalenia. Takie podejście wskazuje, że człowiek w kontekście kultury pełni podwójną rolę. Z jednej strony jest podmiotem aktów, $z$ drugiej przedmiotem i motywem zmian. $Z$ tej racji, dokonująca się w człowieku i poprzez człowieka, intelektualizacja natury wymaga wypracowania sprawności, które wspomagają ten proces. Człowiek bowiem pierwotnie doskonali (aktualizuje) to, co w nim samym potencjalne, a nie to, co dostrzeże jako potencjalne w otaczającym go świecie. W ujęciu Krąpca podstawowe odniesienie do świata jest odniesieniem do czegoś zaktualizowanego. Człowiek najpierw poznaje samego siebie (stwierdza swoje istnienie) jako rozpoznanego w kontekście poznania rzeczywistości ${ }^{5}$. Dopiero na tej bazie następuje usprawnienie do bycia podmiotem poznającym, dokonujące się poprzez zaczątkowe aktualizowanie swoich zdolności intelektualnych. W perspektywie intelektualizacji natury człowiek jawi się więc jako pierwszy czynnik podlegający aktualizacji. Kultura nie dotyczy bezpośrednio natury rozumianej jako zewnętrzny względem człowieka świat. Natura jako świat przyrody, zdeterminowany we właściwy sobie sposób, może sprawnie funkcjonować bez ingerencji człowieka. Tak pojęta natura może być jedynie środkiem dla kultury, głównym zaś jej odniesieniem jest natura ludzka, czyli człowiek uprawiający-doskonalący swe zdolności osobowe.

\footnotetext{
${ }^{4}$ Por. KRĄPIEC, Człowiek i kultura, 9. Etymologię słowa cultura Cyceron wydobywa z analogii do określenia uprawy roli (ager, gen. agri) przez rolnika (agricultura), por. Marcus Tullius Cicero, Rozmowy tuskulańskie, przeł. Józef Śmigaj, w: Marcus Tullius Cicero, Pisma filozoficzne, t. III (Warszawa: Państwowe Wydawnictwo Naukowe, 1961), II, 5.

${ }^{5}$ Por. Mieczyslaw A. KRĄPIEC, Metafizyka. Zarys teorii bytu (Lublin: Redakcja Wydawnictw KUL, 1978), 110-111. Problematykę podmiotowego sądu egzystencjalnego w kontekście poznania istnienia rzeczywistości przedstawia Piotr Stanisław Mazur w monografii Zarys podstaw filozofii człowieka (Kraków: Księgarnia Akademicka, 2016), 101-125.
} 
Specyfika uprawiania tak pojętej natury nie będzie zatrzymywała się na przemianach determinujących rozwój funkcji życiowych (wegetatywnych), ale zasadniczo będzie polegać na doskonaleniu ludzkich zdolności poznawczych. Jest to w zakresie własności osobowych czynnik dominujący, który ma pierwszoplanowy wpływ na procesy rozwojowe zachodzące w człowieku. Dlatego odpowiadającą im sferą jest przede wszystkim pole intelektualnego funkcjonowania człowieka. I w tym zakresie dokonuje się ludzki wymiar tego doskonalenia. Tak więc perspektywą doskonalenia natury człowieka będzie intelektualne determinowanie wszelkich aktów osobowych, które w znacznej mierze mają wpływ także na jego funkcje cielesne. Różnorodność występujących w kulturze zjawisk będzie wynikać z nierównomiernej aktualizacji potencjalności u poszczególnych osób, co w dłuższej pespektywie przybiera postać zróżnicowania i zindywidualizowania ludzkich działań. Do tego dochodzi charakterystyczne dla człowieka zjawisko, występujące w kontekście intelektualizacji, przystosowywania ze względu na własny rozwój elementów świata zewnętrznego. W ten sposób powstaje kultura wytworów, która nie stanowi jednak podstawowego zadania w procesach tworzenia kultury. Rozwój człowieka nie może dokonywać się w „świecie pozaosobowym”. Dlatego pierwszoplanowym odniesieniem dla kultury pozostaje sam człowiek, który stanowi przedmiot intelektualizacji $\mathrm{w}$ zakresie potencjalności jego rozumnej natury.

To sprzężenie w człowieku podmiotowej i przedmiotowej płaszczyzny powstawania kultury będzie kumulować się w specyfice funkcjonowania intelektu. Nie chodzi tu jednak tylko o możliwości czysto poznawcze. Odnosząc się do funkcji intelektu, należy wziąć pod uwagę bogactwo zachodzących w nim operacji, które dokonują się w ramach intelektu lub jako pokierowane przez intelekt ${ }^{6}$. W kulturze stwierdzamy bowiem istnienie wielu różnorodnych zjawisk, które wykraczają poza czysto poznawcze uwarunkowania. W tym zakresie nie mamy do czynienia $\mathrm{z}$ jednowymiarowym sposobem funkcjonowania intelektu, ale szukając uzasadnień dla występujących w kulturze zjawisk ostatecznie dochodzimy do intelektu jako ich przyczyny wzorczej. Operacje intelektualne przybierają formę zróżnicowaną, uwarunkowaną specyfiką zachodzących relacyjnych odniesień przedmiotowych oraz spełnianych przez nie funkcji. Takie kompetencje odnajdujemy w sprawnościach intelektualnych. Stają się one podstawowym celem w doskonaleniu aktów osobowych oraz uzasadnieniem dla występujących w kulturze artefaktów. Dlatego

\footnotetext{
${ }^{6}$ Szersze omówienie tego zagadnienia: Piotr Stanisław MAZur, O nazwach intelektu (Lublin: Wydawnictwo KUL, 2004).
} 
koncentracja na intelektualizacji wymaga zwrócenia uwagi na sprawności intelektualne człowieka oraz na ich możliwości kulturotwórcze.

Koncepcja sprawności intelektualnych jest rozpatrywana głównie w tradycji filozofii klasycznej. Szczególnego wymiaru nabiera ona w kontekście Arystotelesowego rozumienia sprawności jako pewnego rodzaju dyspozycji ${ }^{7}$. Sprawności powstają na bazie różnorodnych doświadczeń — działań i wysiłków podejmowanych przez człowieka - które składają się na jego wewnętrzne „mienie-uposażenie” (gr. "̌̌ıı [héxis], łac. habitus). W perspektywie dokonującego się na tej podstawie usprawnienia sprawności przybierają formę trwałych dyspozycji (cnót), mających wpływ na realizowanie czynności odpowiadających poszczególnym władzom. W sposób szczególny realizuje się to w zakresie sprawności intelektualnych (dianoetycznych) oraz moralnych (etycznych). Z perspektywy realizowania się poszczególnych sprawności należy jeszcze zwrócić uwagę na dominującą rolę władz umysłowych w życiu człowieka. Nie ograniczają się one tylko do obszaru intelektualnych operacji poznawczych, ale są obecne we wszelkich aktach osobowych ${ }^{8}$. Dlatego sprawności intelektualne w zakresie udziału władz umysłowych w działaniu stanowią warunek konieczny, choć niewystarczający dla funkcjonowania cnót moralnych.

Funkcjonowanie sprawności intelektualnych nie sprowadza się tylko do sfery poznawczej, chociaż na aktach poznawczych są one nabudowane. Charakterystyką tych sprawności są wyspecjalizowane dyspozycje, które kształtują się w pierwszym rzędzie poprzez adekwatne ujęcie rzeczywistości. Dlatego jedną z podstawowych sprawności intelektualnych jest poznawalność pierwszych zasad (gr. voṽ [nous], łac. intellectus principiorum), która stanowi ogląd rzeczy w tym, co jest podstawowym odniesieniem dla odpowiedniego jej poznania. Sprawność intelektualnego ujmowania pierwszych zasad jest wyrazem zdolności do poznania relacyjnego sposobu istnienia bytu w sobie oraz jego relacji do innych bytów. W ten sposób dochodzimy do intelektualnego respektowania pierwszych zasad w poznaniu i działaniu? W tym zakresie stanowi ona też podstawę dla innych sprawności intelektualnych, które kształtują się na bazie odczytania pierwszych zasad byto-

\footnotetext{
${ }^{7}$ Sprawności intelektualne Arystoteles najobszerniej omawia w księdze VI Etyki nikomachejskiej — por. ARISTOTLE, Nicomachean Ethics, przeł. H[arris] Rackham (Cambridge, London: Loeb Classical Library, 1956), 1139 b - 1142 a.

${ }^{8}$ Por. Mieczysław A. KrĄPIEC, Czlowiek jako osob (Lublin: Polskie Towarzystwo Tomasza z Akwinu, 2009), 42-45.

${ }^{9} \mathrm{~W}$ tradycji arystotelesowsko-tomistycznej wskazuje się na podwójną rolę tej sprawności, nie tylko w porządku poznania, ale także w porządku działania, gdzie określa się ją mianem synderezy. Por. Wojciech DASZKIEwICZ, Intuicja intelektualna $w$ metafizyce (Lublin: Towarzystwo Naukowe KUL, 2014), 120-128.
} 


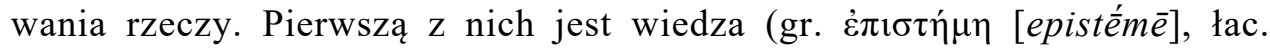
scientia), która stanowi sprawność formułowania sądów dotyczących rożnych aspektów rzeczywistości. Nie są to tylko bezpośrednie sądy stwierdzające istnienie czegoś, ale sądy formułowane jako wnioski wynikające z poznawanych aspektów rzeczy. Zachodzą bowiem w sferze intelektualnej operacje wiedzotwórcze, które opierają się na szeroko pojętych procesach rozumowania. Na takiej podstawie kształtuje się sprawność określana jako mądrość (gr. бọía [sophía], łac. sapientia), która jest intelektualnym dążeniem do ukazania ostatecznych uzasadnień w każdym porządku poznawczym. $Z$ tej racji nie należy zawężać tej sprawności do sposobu gromadzenia informacji o świecie, ale pojmować ją jako stałą dyspozycję do poznawania ostatecznych zasad i przyczyn rzeczywistości ${ }^{10}$. Mądrość stanowi naturalną konsekwencję i syntezę tego, co dokonuje się w ramach sprawności poznania pierwszych zasad oraz operacji wiedzotwórczych.

Wymienionej grupy sprawności intelektualnych nie należy traktować tylko w porządku naukowo-badawczym. Procedurom realizowania się tych sprawności z pewnością odpowiada możliwość tworzenia nauk teoretycznych. Warto jednak podkreślić narzędny charakter sprawności, który pozwala na różnorodne sposoby ich funkcjonowania. Dlatego zastosowanie tych sprawności może dokonywać się także w odniesieniu do przystosowania i organizowania sobie życia w kontekście różnych okoliczności. W ludzkim poznaniu mamy do czynienia ze zmienną i niekonieczną w swym istnieniu rzeczywistością. Jednocześnie znaczna część rzeczywistości pozostaje poza zasięgiem poznania ludzkiego. Dlatego Arystoteles wskazuje też na sprawności intelektualne, w których mamy do czynienia z uwiarygodnianiem sądów

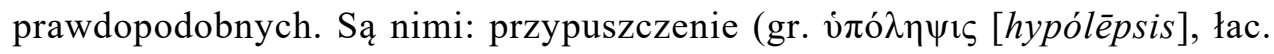
suspicio), odnoszące do poznawania niepełnego, pozostawiającego niepew-

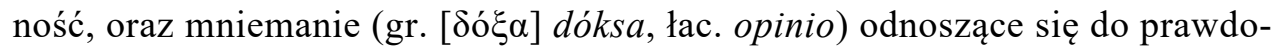
podobnych sądów powszechnych. Jerzy Kalinowski zwraca uwagę, że Arystoteles używa tych terminów zamiennie, co wskazywałoby na wspólne podłoże sprawnościowe tych dwóch dyspozycji ${ }^{11}$. Ujawniają one swoją wartość w procesach uwierzytelniania.

\footnotetext{
${ }^{10}$ Por. Stanisław KAMIŃSKI, „Nauka i filozofia a mądrość”, w: TENŻE, Jak filozofować? Studia z metodologii filozofii klasycznej (Lublin: Towarzystwo Naukowe KUL, 1989), 55-56. Étienne Gilson wskazuje, że wymienione sprawności są wzajemnie podporządkowane i zhierarchizowane - por. Étienne GiLson, Tomizm. Wprowadzenie do filozofii św. Tomasza z Akwinu, przeł. Jan Rybałt (Warszawa: Instytut Wydawniczy PAX, 1998), 303-304.

${ }^{11}$ Por. Jerzy KALINOWSKI, Teoria poznania praktycznego (Lublin: Towarzystwo Naukowe KUL, 1960), 27-29 i 38-39. Kalinowski sprowadza te sprawności do typów rozumowań uprawdopodabniających.
} 
Ludzkie postępowanie także wymaga od człowieka doskonalenia się poprzez sprawności intelektualnie. W tym jednak zakresie nie ogranicza się ono tylko do wymienionych wyżej sprawności poznania zasad, wiedzy i mądrości. Towarzyszą im, wyróżniane w porządku intelektualnym, jego funkcje praktyczne, czyli sprawności rozumnego działania (roztropności) oraz ro-

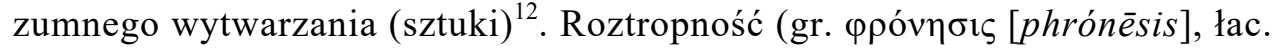
prudentia) stanowi sprawność w dokonywaniu osądu, który uwarunkowany jest osiągnięciem odpowiedniego celu działania. Dlatego w roztropności następuje koncentracja na aktach poznawczych, które pozwolą na dobór środków odpowiednich do pokierowania procesem decyzyjnym i zrealizowaniem tego celu. Natomiast sprawność określana jako sztuka (gr. $\tau \varepsilon \dot{\chi} \vee \eta$ [téchnē], łac. ars) już ze względów terminologicznych wydaje się być mało precyzyjna. W tym przypadku następuje koncentracja na sprawności w tworzeniu jako czynności. Dlatego w sposób szczególny odpowiada mu grecki termin $\tau \dot{\varepsilon} \chi v \eta[t e ́ c h n \bar{e}]$, ponieważ zawiera $\mathrm{w}$ sobie akcent na metodyczne odkrywanie umiejętności, czyli sprawności odpowiedniego wytwarzania. Szeroki zakres stosowania tej sprawności ujawnia się we wszelkich działaniach twórczych, w których znajomość reguł tworzenia, a w konsekwencji umiejętność wytworzenia czegoś czy posługiwania się czymś jest synonimem tak pojętej sztuki.

Wstępny przegląd sprawności intelektualnych, rozpatrywanych z perspektywy człowieka jako twórcy kultury, wskazuje na zależność, jaka zachodzi między tymi sprawnościami a ujawniającymi się w sferze międzyosobowej rezultatami procesów kulturotwórczych. Choć sprawności te stanowią metodę intelektualnego doskonalenia aktów człowieka i nie należy ich utożsamiać z samymi rezultatami osiąganymi w ramach ich funkcjonowania, to relacja, jaka tworzy się w procesach kulturotwórczych, ukazuje przede wszystkim specyfikę doskonalenia się człowieka jako bytu osobowego. Każda z wymienionych sprawności bezpośrednio lub pośrednio znajduje swoje odzwierciedlenie w kulturze, co szczególnie wyraża się poprzez wyróżnienie dziedzin kulturowego działania człowieka. Wartością nadrzędną przy filozoficznym badaniu kultury wydaje się jednak ukazanie podstawowego kryterium doskonalenia człowieka jako osoby, którego kultura jest właściwie wypadkową. W tej perspektywie badawczej mechanizmy funkcjonowania sprawności intelektualnych są w porządku czynnościowym sposobem rozumienia intelektualizacji jako zasady powstawania kultury.

\footnotetext{
${ }^{12}$ Problematykę dotyczącą liczby sprawności intelektualnych oraz odpowiedniego ich uporządkowania rozważa Jerzy Kalinowski w artykule: „Arystotelesowska teoria sprawności intelektualnych czyli o dwu pojęciach mądrości”, Roczniki Filozoficzne 5, z. 4 (1955-1957): 45-65.
} 
W perspektywie rozwoju osobowego człowieka sprawności intelektualne nie są czynnikiem wystarczającym. Doskonalący sposób ich funkcjonowania wyraża się poprzez odniesienia przedmiotowe, które stanowią impuls do zaistnienia procesu intelektualizacji. Funkcjonowanie sprawności intelektualnych ujawnia się w momencie kontaktu poznawczego z tym, co oddziałuje na podmiot aktualizująco. Dopiero w dalszej perspektywie uzyskane na tej drodze dane mogą stać się przedmiotem innych operacji intelektualnych. Stąd hierarchiczny (do pewnego stopnia) jest porządek następowania po sobie poszczególnych sprawności. W tym kontekście ważnym czynnikiem jest także struktura bytowa człowieka, która nie ogranicza się tylko do sfery intelektualnej, a uwarunkowania poznawcze nie funkcjonują w niej w sposób wyizolowany. W ramach władz umysłowych towarzyszy jej sfera wolitywna, a wzajemne uwarunkowania tych dwóch władz biorą udział chociażby w działaniu moralnym człowieka. Do tego dochodzą jeszcze władze zmysłowe, które nie tylko wspomagają transmisję danych, ale także mają wpływ na funkcjonowanie procesów poznawczych i wolitywnych w człowieku. Dlatego proces intelektualizacji, oparty na sprawnościach intelektualnych, nie jest zawężony do jednej z władz, ale stanowi pełny wyraz osobowego życia człowieka.

Pokierowane przez intelekt akty osobowe realizują się jako różne zakresowo działania kulturowe, które tradycja filozofii arystotelesowsko-tomistycznej porządkuje w czterech działach kultury: $\theta \varepsilon \omega \rho i ́ \alpha$ [theōría], $\pi \rho \tilde{\alpha} \xi 1 \varsigma$ [prá-

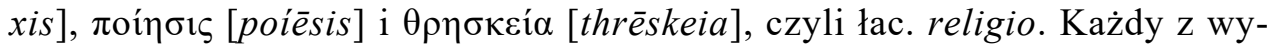
mienianych działów opiera się na odmiennym odniesieniu celowościowym, które specyfikuje określone ludzkie dążenia: prawdę, dobro, piękno i świętość ${ }^{13}$. Jednocześnie każdy $\mathrm{z}$ tych działów, w myśl definicji kultury, stanowić powinien określony rezultat intelektualizacji. Należy więc pokazać, jak ten proces intelektualizacji realizuje się w poszczególnych działach, a właściwie - w jaki sposób dochodzi do wyróżnienia takich, a nie innych działów. Kalinowski zauważa, opierając się na tekstach Arystotelesa, że wymienione trzy pierwsze działy są rodzajami poznania, koniecznymi do realizacji właściwych im celów poznawczych. Równocześnie jednak dodaje, że odniesienie do celu nie jest wystarczające do wyróżnienia tych działów. Musimy wcześniej wskazać przedmiot poznania i specyfikę jego ujmowania przez człowieka $^{14}$. Taka procedura wymaga przyjrzenia się intelektualizacji od

\footnotetext{
${ }^{13}$ Por. DAszKiewicz, Byt. Człowiek. Kultura, 351-364.

${ }^{14}$ Por. KALINOWSKI, Teoria poznania praktycznego, 13-15.
} 
strony procesu kulturotwórczego, dokonującego się w pierwszym rzędzie w podmiocie. Nic bowiem nie zostałoby utworzone jako „dzieło” kulturowe, gdyby nie dokonała się intelektualna aktualizacja czynnika potencjalnego w człowieku lub przez człowieka.

Ze względu na potencjalny charakter ludzkiej postawy intelektualno-poznawczej wszelkie sprawności mogą aktualizować się dopiero w zetknięciu z tym, co aktualne. Dlatego intelektualizacja to $\mathrm{w}$ pierwszym rzędzie pokierowanie rozumu przez to, co aktualne (realne), co nie musi być rozpoznane zupełnie i całościowo, lecz tylko w zakresie tego, co w danym poznaniu aktualizuje, czyli pokieruje władze poznawcze ${ }^{15}$. W tym kontekście w tradycji arystotelesowsko-tomistycznej stosuje się sformułowanie recta ratio, przez które określa się procedurę zachodzenia procesów intelektualizujących w człowieku. Recta ratio stanowi poznanie dokonujące się według praw przedmiotu poznawanego, którego rezultaty wyznaczają sposoby intelektualnego ujmowania tego przedmiotu. Pierwszorzędnie realizuje się więc sprawność poznawania pierwszych zasad, której funkcjonowanie zaczyna się już na poziomie poznania przednaukowego, ujmującego byt w aspektach koniecznych. Poprzez sprawność wiedzotwórczą dokonuje się poznanie zreflektowane, w którym mamy do czynienia z pierwszą formą porządkowania tego, co poznane jako układ rzeczy (speculabile). Dokonuje się to poprzez uświadomione i uzasadnione ukierunkowanie na dany aspekt poznawczy, pozwalający na racjonalne zrozumienie rzeczywistości - recta ratio speculabilium $^{16}$. W ten sposób rozpoczyna się funkcjonowanie sprawności intelektualnych, a w porządku kulturotwórczym — proces intelektualizacji.

$\mathrm{Na}$ tym etapie, w sposób adekwatny do odniesienia przedmiotowego, następuje pierwsze rozróżnienie działu kultury. Dokonuje się ono na poziomie zreflektowanym, gdzie $\mathrm{w}$ ramach recta ratio speculabilium kształtują się podstawy poznania naukowego, które przybiera postać zorganizowaną. Na tej bazie zostaje wyróżniony dział kultury jako $\theta \varepsilon \omega \rho i ́ \alpha$ [theōría]. Porządek poznawczy, w swym sprecyzowanym metodologicznie podejściu, jest w stanie wydobyć z układu rzeczy elementy koniecznościowe, które fundują

\footnotetext{
${ }^{15}$ Por. Mieczysław A. KRĄPIEC \& Stanisław KAMIŃSKI, „Specyficzność poznania metafizycznego", Znak 13, nr 5 (1961): 606-608. Autorzy proponują w tym kontekście zastosować rozróżnienie etapów poznawczych na „konstrukcję naturalną” i „konstrukcję sztuczną”, co wskazuje na intelektualne przejście dokonujące się w ramach ludzkiego poznania.

${ }^{16}$ Por. Mieczysław A. KRĄPIEC, „Podstawy klasyfikacji poznania i nauk”, Roczniki Filozoficzne 9, z. 1 (1961): 6-9. Krąpiec podkreśla, że tylko w ramach recta ratio speculabiblium mamy do czynienia z poznaniem przednaukowym i zreflektowanym. Dziedziny poznania roztropnościowego i poznania twórczego odnoszą się w tym zakresie do speculabilium.
} 
poszczególne nauki. Zróżnicowanie nauk uwarunkowane jest przede wszystkim aspektem badań (przedmiotem formalnym) oraz metodologicznymi procedurami badawczymi. Procesy te powodują, że w ramach $\theta \varepsilon \omega \rho i ́ \alpha$ [theōría] tworzy się pole dla aktualizacji sprawności intelektualnych, w którym mogą występować różne formy aktywności naukowej człowieka. Wydaje się jednak, że nie tylko rezultaty w postaci badań naukowych mogą być kulturowym rezultatem, ale także wszelkie dążenia uzasadniające, dzięki którym dochodzi do doskonalenia władz osobowych poprzez funkcjonowanie sprawności wiedzotwórczych ${ }^{17}$. Ostateczną perspektywą doskonalenia jest w tym porządku mądrość, która w koncepcji filozofii arystotelesowsko-tomistycznej stanowi naczelne zadanie dla wiedzy (sapiencjalny charakter nauki). Jako sprawność wykracza ona jednak poza $\theta \varepsilon \omega \rho i ́ \alpha$ [theōría] i wydaje się stanowić także podstawę pod inne działania kulturotwórcze.

Funkcjonowanie wymienionych sprawności intelektualnych dotyczy wszelkich aktów osobowych i nie ogranicza się tylko do sfery $\theta \varepsilon \omega \rho i ́ \alpha$ [theōría]. Każdy następny wymieniony dział kultury ma w swych podstawach intelektualizacyjnych jako bazę recta ratio. Zmieniają się jednak odniesienia przedmiotowe, które ostatecznie determinują charakter realizowanych sprawności. W ramach $\pi \rho \tilde{\alpha} \xi ı$ [práxis] także dochodzi do koncentracji na aktach poznawczych, ale zmieniają się priorytety poszczególnych operacji intelektualnych. Do wymienionych wyżej dochodzi jako sprawność wiodąca — roztropność. Przy realizowaniu się roztropności udział bierze nie tylko czynnik intelektualny, ale także czynnik wolitywny, który uczestniczy we wszystkich czynnościach poznawczych oraz dynamizuje proces ludzkiego działania. Punktem odniesienia w tym porządku jest jednak to, co sprawia działanie (agibile). Charakterystyka tego sprawstwa leży poza podmiotem i wyraża się przez dobro stanowiące motyw działania ${ }^{18}$. W tym kontekście trudniej jest wskazać na sposób realizowania się sprawności intelektualnej, ponieważ nie funkcjonuje ona samodzielnie. Udział czynnika wolitywnego odgrywa ważną rolę w ludzkich aktach decyzyjnych. Nie zachodzi jednak działanie bez jakie-

\footnotetext{
${ }^{17}$ Funkcjonowaniem sprawności wiedzotwórczych może być poznanie zreflektowane, ale nie w pełni racjonalnie uzasadnione, ponieważ na wartość epistemologiczną mogą wpływać inne władze człowieka (np. uczucia czy wola), środowisko, religia itp. $Z$ takim poznaniem mamy do czynienia chociażby w przypadku kształtowania się światopoglądu. Por. Stanisław KAMIŃSKI, „Typy ludzkiej wiedzy”, w: tenże, Jak filozofować?, s. 28-32.

${ }^{18}$ Określenie recta ratio agibilium zostało sformułowane przez Tomasza z Akwinu dla wyrażenia istoty intelektualnego wymiaru ludzkiego działania pokierowanego przez cel jako motyw tego działania - por. S. Thomae AQuinatis Summa theologiae, cura et studio Petri Caramello (Taurini, Romae: Marietti, 1952-62), I-II, q. 57, a. 4.
} 
gokolwiek odniesienia do sfery intelektualno-poznawczej. Dlatego w roztropności następuje koncentracja na aktach poznawczych, które pozwalają na rozpoznanie dobra jako celu oraz dobór środków odpowiednich do pokierowania procesem decyzyjnym i zrealizowaniem rozpoznanego celu. W ten sposób dokonuje się aktualizacja osobowych zdolności wolitywnych przez intelektualizację w porządku działania. Konsekwencją tej intelektualizacji jest ukształtowanie się $\pi \rho \tilde{\alpha} \xi 1 \varsigma$ [práxis] jako działu kultury.

Wskazaliśmy wcześniej, że w aspekcie sprawności intelektualnych, rozumną działalność praktyczną człowieka, realizującą się przez roztropność, odróżniamy od rozumnej działalności wytwórczej, realizującej się przez $\tau \dot{\chi} \chi v \eta$ [téchnē]. Potraktowanie $\tau \dot{\varepsilon} \chi v \eta[t e ́ c h n \bar{e}]$ jako sprawności intelektualnej wynika z wzorczego uwarunkowania procesów wytwórczych. Także i w tym kontekście występuje udział innych sprawności intelektualnych, w tym przypadku szczególnie ważna jest sprawność wiedzotwórcza. Odniesieniem przedmiotowym dla $\tau \varepsilon ́ \chi v \eta[t e ́ c h n \bar{e}]$ staje się byt jako układ rzeczy w porząd$\mathrm{ku}$ treściowym ${ }^{19}$. Intelektualne operacje na treściach pozwalają na odtworzenie relacji zgodne $\mathrm{z}$ relacjami występującymi w samej rzeczy poznawanej. Na tej jednak bazie może także zachodzić intelektualne konstruowanie układu relacji jako konsekwencji procesów poznawczych, w których kryterium zgodności z poznawaną rzeczą zostaje zastąpione przez kryterium kreatywności (factibile). W tych procesach biorą udział także inne władze poznawcze. Szczególną rolę pełni w nich sfera wyobraźni, która stanowi czynnik wspomagający w stosunku do sfery intelektualnej. Na poziomie wyobraźni dokonuje się unaocznienie możliwości kreatywnych, wynikające z powiązania wyobrażeń ze sferą zmysłową. Istotną rolę w tym procesie pełni tzw. wyobraźnia twórcza, w której wyobrażenia, posiłkując się pamięcią, mogą nakładać się na inne wyobrażenia ${ }^{20}$. Ten związek dostrzegany jest przez intelekt jako podstawa procesu kreatywnego umocowanego w ukonkretnionych „obrazach” zmysłowych.

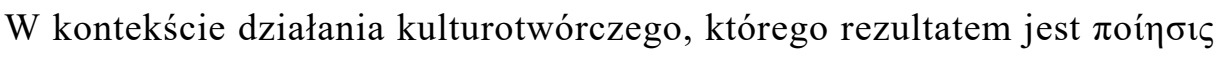
[póiēsis], sprawność $\tau \dot{\chi} \chi v \eta$ [téchnē] stanowi podstawę dla zachodzącej w tym zakresie intelektualizacji jako recta ratio factibilium. Specyfika powstałych

\footnotetext{
${ }^{19}$ Pomijamy tu problematykę funkcjonowania twórczości, występującą jako konieczny czynnik w procesach poznawczych (np. w konstruowaniu pojęć). Nie są to akty czysto twórcze, ponieważ udział podmiotu poznającego w tym procesie jest uwarunkowany treścią poznawanej rzeczy. Celem natomiast jest adekwatne „odtworzenie” tej treści w jej relacyjnym układzie, a nie tworzenie jakiegoś nowego układu.

${ }^{20}$ Por. Mieczysław A. KRĄPIEC, Realizm ludzkiego poznania (Lublin: Redakcja Wydawnictw KUL, 1995), 430-436.
} 
na tej drodze procesów opiera się na doborze kryterium, które wyznacza odpowiedni sposób konstruowania układu relacji treściowych dla poszczególnych działań twórczych. Już bowiem czysto poznawcze ujęcia stanów rzeczy $w$ ich znakowym wymiarze przybierają postać intencjonalną. To pozwala na sformułowanie analogicznego zastosowania treści poznawczych, uwarunkowanych jednak analogicznością rzeczy, a nie myśli. Dlatego aby osiągnąć akt twórczy, należy w doborze kryterium kierować się poznawczo ujmowaną treścią, która wyznacza możliwość realizacji takiego aktu. Dzięki treściowemu rozpoznaniu poznawanej rzeczy otrzymujemy reguły możliwego sposobu jej modyfikowania. To pozwala na przejście do obszaru wytworu, które dokonuje się poprzez odpowiednio skonstruowaną strukturę, analogiczną do potencjalności rzeczywistych stanów rzeczowych (intencjonalność wtórna). Dostrzeżenie możliwości zrealizowania się tego, co intencjonalne w materiale zewnętrznym musi być jednocześnie odkryciem możności tego materiału. To sprzężenie jest wyrazem stopnia multiplikacji, jaki zachodzi w procesach

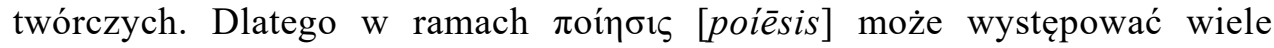
różnorodnych umiejętności wytwórczych, dla których przyczyną wzorczą ich powstawania oraz funkcjonowania w kulturze jest factibilium.

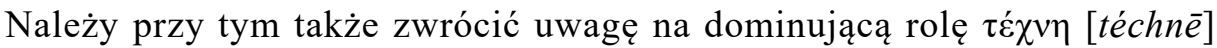
we wszelkich formach działania kulturotwórczego. Nie ogranicza się ona

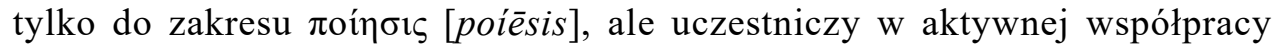
z innymi sprawnościami, tworząc właściwie fundamentalną zdolność kulturotwórczą ${ }^{21}$. Wynika to $z$ intencjonalnego charakteru całej kultury i pozwala na wytłumaczenie obecności czynników twórczych w doskonaleniu wszelkich aktów osobowych człowieka. W tym kontekście intelektualizacja wydaje się być podstawowym warunkiem zaistnienia procesu twórczego jako działania kulturotwórczego. Przy tym nie należy rozumieć kultury jako rezultatu twórczej konstrukcji intelektualnej, ale jako rezultat osobowego sposobu doskonalenia się człowieka.

Specyfika intelektualizacji zachodząca $w$ ramach ostatniego działu kultury, jakim jest religio, odbiega od wcześniejszych form tłumaczenia udziału sprawności intelektualnych. Wyjaśniania religii w kulturze nie można rozpoczynać od zastanych faktów religijnych. Zanim bowiem zaistnieje osobowa więź z Absolutem, musi wystąpić w podmiocie jakaś forma intelektualizacji, dzięki której ta relacja będzie mogła świadomie się realizować. Wyjaśniając proces intelektualizacji w tym obszarze, musimy odnieść się do sprawności intelektualnych, które pozwalają człowiekowi na uwiarygodnianie tego, co

\footnotetext{
${ }^{21}$ Por. KRĄPIEC, Człowiek i kultura, 238-243.
} 
nie w pełni rozpoznane. Taki sposób funkcjonowania sprawności przypisywany jest przypuszczeniu i mniemaniu. Nieodłącznym czynnikiem każdego

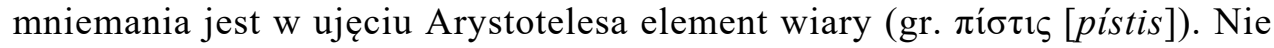
chodzi tu jednak o wiarę $\mathrm{w}$ sensie czysto religijnym, ale o wiarę rozumianą jako przekonanie o prawdzie ${ }^{22}$. Funkcjonowanie mniemania jako sprawności intelektualnej polega na przyjęciu czegoś niepewnego za prawdziwe. Podstawą uznania czegoś za prawdziwe jest więc jakaś forma uwiarygodnienia. W sposób konieczny tak rozumianemu mniemaniu towarzyszy wątpliwość, która jest cechą charakterystyczną funkcjonowania przypuszczenia. W połączeniu funkcjonowania tych dwóch sprawności jako czynnik pozytywny występuje wiara, czyli przekonanie nakierowane na uznawanie odkrywanych prawd niepewnych. W ten sposób konstytuuje się w człowieku wyjątkowa postawa intelektualno-poznawcza, która dopuszcza przyjęcie czegoś za prawdziwe na podstawie wiary.

Wiara jednak jako akt osobowy sięga jeszcze głębiej w strukturę człowieka, ponieważ w przekonywaniu udział bierze nie tylko sfera poznawcza, ale musi także wystąpić decyzja o przyjęciu tego przekonania jako czegoś prawdziwego. Poznanie niepewne w dyskursie naukowym jest odrzucane, natomiast $\mathrm{w}$ dyskursie pozanaukowym może być przyjęte na podstawie innych czynników. $Z$ tej racji nieodzownym czynnikiem dla wiary są akty wolitywne. Dokonuje się to w dwóch etapach. Na pierwszym etapie następuje uznanie czegoś za wiarygodne, a motywy tego uznania są oparte na różnych sposobach wartościowania danych (także pozaracjonalnych). Na drugim etapie to, co wiarygodne, jest uznawane za pewne. Pewność w porządku zawierzeń uzyskuje się więc pod wpływem wyboru motywów uwiarygodniających $^{23}$. W ten sposób, poprzez wybór w akcie woli, człowiek może przyjmować nieoczywiste i bezpośrednio nierozpoznawalne treści poznawcze. Jest to więc proces, w którym funkcjonowanie sprawności intelektualnych wymaga udziału czynnika wolitywnego. Wola jednak nie odgrywa tu roli dynamizującej ten proces (jak wcześniej przy działaniu moralnym), ale stanowi element subiektywny, wspomagający poznawcze warunki uznawania

\footnotetext{
${ }^{22}$ Por. Arystoteles, $O$ duszy, przeł. Paweł Siwek, w: Arystoteles, Dzieła wszystkie, t. 3 (Warszawa: Wydawnictwo Naukowe PWN, 1992), 428 a 20-25. William M.A. Grimaldi wska-

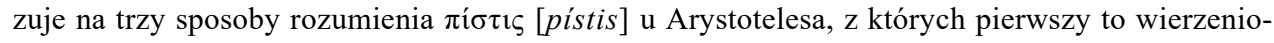
we ukierunkowanie intelektu ludzkiego - por. William M.A. Grimaldi, Studies in the Philosophy of Aristotle's Rhetoric (Wiesbaden: Franz Steiner Verlag, 1972), 58-59. Szczególne znaczenie $\pi i ́ \sigma \tau \iota \varsigma$ [pistis] ma dla argumentacji retorycznej, traktowanej jako sposoby uwierzytelniania w komunikacji perswazyjnej — por. ARYstoteles, Retoryka. w: tenże, Retoryka. Poetyka, przeł. Henryk Podbielski (Warszawa: Państwowe Wydawnictwo Naukowe, 1988), 1355 a 3-7.

${ }^{23}$ Por. KAMIŃSKI, „Typy ludzkiej wiedzy”, 27-28.
} 
sądów o rzeczywistości. Charakter dynamizujący w tym procesie pełni sfera intelektualna, w której występuje dążenie do selekcji oraz weryfikacji przyjmowanych treści.

Ukazanie wiary jako sposobu funkcjonowania intelektualizacji nie jest warunkiem wystarczającym dla wyróżnienia w kulturze działu religio. Akty religijne nie są bowiem ugruntowane tylko na podmiotowych sprawnościach. Występuje w tym przypadku jeszcze uwarunkowanie ontyczne, które stanowi podstawę relacyjnego odniesienia do Absolutu. Tym uwarunkowaniem jest bytowa przygodność, której konsekwencją jest spotencjalizowana natura człowieka. Religia jest więc formą osobowego umocnienia bytowania człowieka wobec doświadczanej przygodności. Dlatego w perspektywie egzystencjalnej niewystarczalności oraz osobowej potencjalności człowiek kształtuje w sobie relację do tego, co doskonałe i co może stanowić ostateczne uzasadnienie jego istnienia ${ }^{24}$. Na tym etapie decydującą rolę odgrywa wiara jako intelektualna dyspozycja do przyjęcia tego, co bezpośrednio nierozpoznane, ale co poprzez świadectwa uznajemy jako doskonałe. W tym kontekście wskazuje się na Absolut jako na kres tej relacji. Tak więc religia, jako akt osobowy człowieka, kulturowo ujawnia się poprzez intelektualizację rozumianą jako recta ratio, której odniesienie przedmiotowe jest trudne do jednoznacznego określenia. Wyraża się ono bowiem poprzez zdolność do zawierzenia oraz decyzję o uznaniu tego, co jawi się jako Absolut, a co występuje w kontekście doświadczenia przygodności.

\section{WNIOSKI}

W obszarze badań filozoficznych kultura stanowi wciąż zbyt mało doprecyzowany przedmiot badawczy. Nie jest on tylko rezultatem wielości danych kulturowych czy też nie sprowadza się do dynamizmu powstawania faktów kulturowych, ale wiąże się raczej z metodą prowadzenia badań nad kulturą. Filozoficzne badanie kultury nie może opierać się tylko na stwierdzeniu istnienia różnych faktów kulturowych w otaczającym nas świecie, ale musi poszukiwać racji powstawania takich faktów. Dlatego nie będzie wystarczającą procedurą badawczą jedynie opis i klasyfikacja danych kulturowych. Filozofia w pierwszym rzędzie musi odnieść się do człowieka jako do twórcy kultury, ukazując specyfikę zachodzących w nim procesów kulturotwórczych. Propozycja określenia kultury jako intelektualizacji natury, zapropo-

\footnotetext{
${ }^{24}$ Por. KRĄPIEC, Człowiek i kultura, 38-41.
} 
nowana przez Mieczysława A. Krąpca, wydaje się być odpowiednim rozwiązaniem wobec wymagań metodologicznych stawianych filozoficznym badaniom nad kulturą.

Definiowanie kultury jako intelektualizacji natury odzwierciedla od strony czynnościowej proces, w którym poprzez udział intelektu dokonuje się aktualizacja osobowych potencjalności człowieka. Ten proces nie jest w pierwszym rzędzie nakierowany na realizację wytworów kulturowych, ale na udoskonalające człowieka uaktywnienie jego rozumnej natury. Dlatego proces intelektualizacji w człowieku rozpoczyna się od momentu styku poznawczego z rzeczywistością, w którym każdy, nawet nie w pełni uświadomiony akt poznawczy, powoduje rozwój spotencjalizowanych władz osobowych. W tym kontekście ujawnia się też funkcjonowanie intelektualnych sprawności, dzięki którym dochodzi do porządkowania ludzkich aktów poznawczych. I to właśnie na bazie intelektualnych sprawności (cnót dianoetycznych) proces intelektualizacji możemy określić kulturą — „uprawą duszy”. Tradycja arystotelesowsko-tomistyczna precyzuje ten proces, wskazując na różne formy i udział tych sprawności w intelektualnych aktach osobowych. To przekłada się na wyjaśnienie sposobów funkcjonowania sfery intelektualnej w człowieku, a jednocześnie ukazuje rezultaty tego funkcjonowania, którymi są wyróżniane aktywności twórcze.

W takiej koncepcji wyróżnione w ramach kultury specyficzne działy:

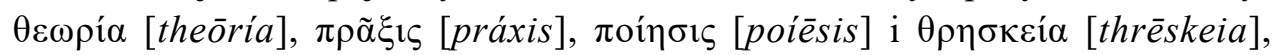
czyli łac. religio, zyskują dzięki sprawnościom intelektualnym uzasadnienie w ramach procesu intelektualizacji. Spójność jaka zachodzi w tym kontekście między rozumieniem natury a jej intelektualną determinacją wyraża się poprzez recta ratio, czyli pokierowane, przez odkrywany w przedmiocie układ relacji, sposoby doskonalenia się człowieka, których rezultatem są odpowiednie formy intelektualnego ujmowania tego przedmiotu. Taka procedura zachodzenia procesów intelektualizacyjnych w człowieku prowadzi do działań kulturotwórczych, których wyrazem są fakty kulturowe klasyfikowane w ramach wyróżnionych działów. Rozumienie intelektualizacji jest więc od strony czynnościowej sposobem realizowania się sprawności intelektualnych, których funkcjonowanie przybiera formę odpowiedniego pokierowania intelektu (recta ratio) według praw przedmiotu poznawanego. Dzięki wskazaniu na rolę i miejsce sprawności intelektualnych w działaniach kulturotwórczych intelektualizacja jako proces zyskuje pełniejsze zrozumienie, co pozwala dostrzec mechanizmy powstawania tak różnorodnych w swej istocie faktów kulturowych. 


\section{BIBLIOGRAFIA}

ARistotle. Nicomachean Ethics. Przełożył H[arris] Rackham. Cambridge-London: Loeb Classical Library, 1956.

Arystoteles. Dzieła wszystkie. T. 3: O duszy. Krótkie rozprawy psychologiczno-biologiczne. Zoologia. O częściach zwierząt. Warszawa: Wydawnictwo Naukowe PWN, 1992.

Arystoteles. Retoryka. Poetyka. Przełożył Henryk Podbielski. Warszawa: Państwowe Wydawnictwo Naukowe, 1988.

Cicero, Marcus Tullius. Rozmowy tuskulańskie. Przełożył Józef Śmigaj, W: Marcus Tullius CICERO. Pisma filozoficzne. T. III: Księgi akademickie. O najwyższym dobru i złu. Paradoksy stoickie. Rozmowy tuskulańskie. Warszawa: Państwowe Wydawnictwo Naukowe, 1961.

DAszKIEwICZ, Wojciech. Byt. Człowiek. Kultura. Studium z filozofii kultury. Lublin: Polskie Towarzystwo Tomasza z Akwinu, 2019.

DASZKIEWICZ, Wojciech. Intuicja intelektualna $w$ metafizyce. Lublin: Towarzystwo Naukowe KUL, 2014.

DumA, Tomasz. „Natura miarą sensu kultury”. Zeszyty Naukowe KUL 58, nr 1 (2015): 35-49.

Gilson, Étienne. Tomizm. Wprowadzenie do filozofii św. Tomasza z Akwinu. Przełożył Jan Rybałt. Warszawa: Instytut Wydawniczy PAX, 1998.

GondeK, Paweł. Projekt autonomicznej filozofii realistycznej. Mieczysława A. Krapca i Stanisława Kamińskiego teoria bytu. Lublin: Wydawnictwo KUL i Polskie Towarzystwo Tomasza z Akwinu, 2015.

GRIMALDI, William M.A. Studies in the Philosophy of Aristotle's Rhetoric. Wiesbaden: Franz Steiner Verlag 1972.

KALINOwSKI, Jerzy. „Arystotelesowska teoria sprawności intelektualnych czyli o dwu pojęciach mądrości”. Roczniki Filozoficzne 5, z. 4 (1955-1957): 45-65.

KALINOwSKI, Jerzy. Teoria poznania praktycznego. Lublin: Towarzystwo Naukowe KUL, 1960.

KAMIŃSKI, Stanisław. Jak filozofować? Studia z metodologii filozofii klasycznej. Lublin: Towarzystwo Naukowe KUL, 1989.

KrąPIEC, Mieczysław A. Człowiek i kultura. Lublin: Polskie Towarzystwo Tomasza z Akwinu, 2008.

KrĄPIEC, Mieczysław A. Człowiek jako osoba, Lublin: Polskie Towarzystwo Tomasza z Akwinu, 2009.

KrąPIEC, Mieczysław A. Metafizyka. Zarys teorii bytu. Lublin: Redakcja Wydawnictw KUL, 1978

KRĄPIEC, Mieczysław A. „Podstawy klasyfikacji poznania i nauk”. Roczniki Filozoficzne 9, z. 1 (1961): 5-29.

KrĄPIEC, Mieczysław A. Realizm ludzkiego poznania, Lublin: Redakcja Wydawnictw KUL, 1995.

KRĄPIEC, Mieczysław A., U podstaw rozumienia kultury, Lublin: Redakcja Wydawnictw KUL, 1991.

KrĄPIEC, Mieczysław A., \& Stanisław Kamiński. „Specyficzność poznania metafizycznego”. Znak 13, nr 5 (1961): 602-637.

MAZUR, Piotr Stanisław. O nazwach intelektu. Lublin: Wydawnictwo KUL, 2004.

MAZuR, Piotr Stanisław. Zarys podstaw filozofii człowieka, Kraków: Księgarnia Akademicka, 2016.

S. Thomae Aquinatis Summa theologiae. Cura et studio Petri Caramello. Taurini, Romae: Marietti, 1952-62. 


\section{SPECYFIKA SPRAWNOŚCIOWEGO ROZUMIENIA INTELEKTUALIZACJI W KULTUROTWÓRCZYM DZIAŁANIU CZŁOWIEKA}

\section{Streszczenie}

Propozycja określenia kultury jako ,intelektualizacji natury” stanowi punkt wyjścia do badań nad sposobem rozumienia intelektualizacji. W artykule wskazano, że podstawą dla zachodzenia procesu intelektualizacji są sprawności intelektualne. Intelektualizacja jako sposób realizowania się sprawności intelektualnych jest $\mathrm{w}$ pierwszym rzędzie doskonaleniem człowieka $\mathrm{w}$ jego osobowych potencjalnościach. Dlatego funkcjonowanie sprawności intelektualnych przybiera w procesie intelektualizacji formę odpowiedniego pokierowania intelektu (recta ratio) przez odkrywany w przedmiocie poznawanym układ relacji. Wyróżniane w tym kontekście działy kultury są obszarami osobowego doskonalenia się człowieka, a w dalszej konsekwencji przyczyną powstawania różnorodnych faktów kulturowych.

Slowa kluczowe: kultura; intelektualizacja; sprawności intelektualne; recta ratio.

\section{THE SPECIFICITY OF THE EFFICIENT UNDERSTANDING OF INTELLECTUAL SKILLS IN CULTURE-FORMING HUMAN ACTIVITY}

\section{S u m m a ry}

The suggestion to define culture as "intellectualization of nature" is the starting point for research into the way of understanding an intellectualization. The article indicates that the basis for the process of intellectualisation are intellectual virtues. Intellectualisation as a way of realizing intellectual abilities is first and foremost the improvement of human beings in their personal potentialities. Therefore, the efficiency of intellectual skills in the process of intellectualization takes the form of appropriate directing of the intellect (recta ratio) by the relationship system discovered in the studied subject. The fields of culture (culture domains) highlighted in this context are areas for the personal improvement of man, and, consequently, the cause of various cultural facts.

Key words: culture; intellectualisation; intellectual virtues; recta ratio. 